\title{
Pelatihan Penulisan Proposal Penelitian Tindakan Kelas (PTK) Bagi Guru Ekonomi Kabupaten Sidoarjo
}

\author{
Yoyok Soesatyo \\ Universitas Negeri Surabaya, Indonesia, Yoyoksoesatyo@unesa.ac.id \\ Waspodo Tjipto Subroto \\ Universitas Negeri Surabaya, Indonesia, Indonesia, waspodosubroto@unesa.ac.id \\ Norida Canda Sakti \\ Universitas Negeri Surabaya, Indonesia, Noridacs@yahoo.com \\ Muhammad Edwar \\ Universitas Negeri Surabaya, Indonesia, muhammadedwar@unesa.ac.id \\ Novi Trisnawati \\ Universitas Negeri Surabaya, Indonesia, novitrisnawati@ unesa.ac.id
}

\begin{abstract}
Writing Training of Class Action Research Proposal (TOD/PTK) was held for the MGMP teachers in Sidoarjo Regency which is located at SMANOR Sidoarjo. The Community Service Activities aims to (1) provide information to the trainees about the basic concept of classrooms action research, the essence of class action research (2) to assign the arranging proposal to all participants; (3) giving guidance to all participants about the review of Class Action Research (PTK). This community service activities research using communicative or speech method at the time of giving materials to the participants, discussion and frequently asked questions and the practice of directly compiling a class action research proposal (PTK) and done by the guidance from PKM team. The results obtained community service activities on the classroom action research proposal writing training give benefit to the MGMP economics teacher at Sidoarno Regency. It is because of all participants now are able to arrange their own proposal of class action research, and it is also procide benefits for teachers to continue on making class action research that can be useful for a teacher's promotion.
\end{abstract}

Keywords: class action research, class, proposal, economic

Available at

http://journal.unj.ac.id/unj/index.php/jpm 


\section{PENDAHULUAN}

\section{Anaisis Situasi}

Berdasarkan Peraturan Menteri Negara Pendayagunaan Aparatur Negara dan Birokrasi Reformasi (Permen PAN) Nomor 16 Tahun 2009 Tentang Jabatan Fungsional Guru menjelaskan bahwa syarat kenaikan pangkat bagi guru menjadi golongan III-c ke atas, wajib membuat publikasi ilmiah dan atau karya inovatif. Publikasi ilmiah meliputi hasil penelitian atau gagasan inovatif pada bidang pendidikan formal; dan publikasi buku teks pelajaran, buku pengayaan, dan pedoman Guru. Sedangkan karya Inovatif meliputi menemukan teknologi tepat guna; menemukan/menciptakan karya seni; membuat/memodifikasi alat pelajaran/peraga/praktikum; dan mengikuti pengembangan penyusunan standar, pedoman, soal dan sejenisnya.

Menanggapi adanya kondisi tersebut, para guru ekonomi di tingkat Sekolah Menengah Atas (SMA) Kabupaten Sidoarjo yang tergabung dalam MGMP Sidoarjo membutuhkan kegiatan PTK atau Penelitian Tindakan Kelas yang merupakan karya tulis ilmiah guru untuk perbaikan mutu PBM. Frasa

Available at http://journal.unj.ac.id/unj/index.php/jpm penelitian tindakan kelas dari unsur kata pembentuknya, yakni penelitian, tindakan, dan kelas. Penelitian mengacu pada suatu kegiatan mencermati suatu objek dengan menggunakan cara atau aturan metodologi tertentu untuk memperoleh data atau informasi yang bermanfaat untuk meningkatkan mutu suatu hal yang menarik minat dan penting bagi peneliti. Tindakan mengacu pada suatu gerak kegiatan yang sengaja dilakukan dengan tujuan tertentu. Dalam penelitian tindakan kelas tindakan itu berbentuk rangkaian siklus kegiatan untuk siswa. Penelitian Tindakan Kelas merupakan penelitian yang lebih baik dilakukan oleh guru sebagai pelaksana program KBM di kelas. Sehingga, guru diharuskan menguasai keterampilanketerampilan dalam Penelitian Tindakan Kelas (PTK).

Dengan menanggapi permasalah ini, maka diperlukan pelatihan lebih lanjut tentang "Pelatihan Penulisan Proposal Penelitian Tindakan Kelas (PTK) bagi guru Ekonomi Kabupaten Sidoarjo. 


\section{Perumusan Masalah}

Berdasar uraian di atas maka dapat diidentifikasi permasalahan sebagai berikut:

1. Bagaimanakah pelaksanaan Pelatihan penulisan Peneltian Tindakan Kelas bagi Guru-Guru mata pelajaran Ekonomi SMA di Kabupaten Sidoarjo?

2. Bagaimanakah pola pendampingan penulisan Penelitian Tindakan Kelas bagi guru-guru SMA di Kabupaten Sidoarjo?

\section{Tujuan}

Tujuan Pelatihan dalam Pengabdian Kepada Masyarakat ini adalah untuk :

1. memberikan penyampaian materi pada guru tentang Penelitian Tindakan Kelas (PTK),

2. memberikan penugasan penyusunan proposal pada guru tentang Penelitian Tindakan Kelas (PTK),

3. memberikan pendampingan pada guru tentang telaah proposal Penelitian Tindakan Kelas (PTK) yang telah dibuat oleh guru.

Available at http://journal.unj.ac.id/unj/index.php/jpm

\section{Manfaat}

Manfaat Pelatihan dalam Pengabdian Kepada Masyarakat ini adalah :

1. guru dapat mengetahui lebih dalam tentang materi Penelitian Tindakan Kelas (PTK),

2. guru dapat menyusun proposal Penelitian Tindakan Kelas (PTK),

3. guru dapat menelaah proposal Penelitian Tindakan Kelas (PTK).

\section{KAJIAN TEORITIK}

PTK mempunyai banyak model sehingga peneliti dapat memiliki salah satu model yang sesuai dengan yang dikehendaki. Dalam pemilihan model, tidak ada pertimbangan baku dan peneliti dapat memilih salah satu model yang sesuai dengan tingkat kemampuan. Satu hal yang perlu diperhatikan, bahwa seorang peneliti dapat menggunakan lebih dari satu model. Peneliti melakukan hal ini dalam rangka membandingkan antara model yang satu dengan yang lain dan mencari model mana yang paling efesien dengan hasil paling efektif. Apabila dengan alasan demikian, maka penggunaan berbagai 
model untuk berbagai jenis kasus boleh dilakukan.

Ada beberapa macam pola pelaksanaan PTK yang dikembangkan oleh beberapa ahli, tetapi yang paling terkenal ada 5 (lima) model yaitu: Model Lewin, Model McKernan, Model Ebbut, Model Elliot, dan Model Kemmis \& Mc Taggart. Model-model tersebut memiliki pola dasar yang sama, yaitu serangkaian kegiatan penelitian berupa rangkaian siklus di mana pada setiap akhir siklus akan membentuk siklus baru hasil revisi/perbaikan.

\section{Model Kurt Lewin (1946)}

Model Kurt Lewin, merupakan model yang selama ini menjadi acuan pokok (dasar) dari berbagai model action research, terutama classroom action research (CAR). Lewin adalah orang pertama yang memperkenalkan action research. Konsep pokok action research menurut Lewin terdiri dari empat komponen, yaitu: (1) perencanaan (planning), (2) tindakan (acting), (3) pengamatan (observing), dan (4) refleksi (reflecting). Hubungan keempat komponen itu dipandang, sebagai satu siklus, seperti terlihat pada gambar 3.1.

Available at http://journal.unj.ac.id/unj/index.php/jpm

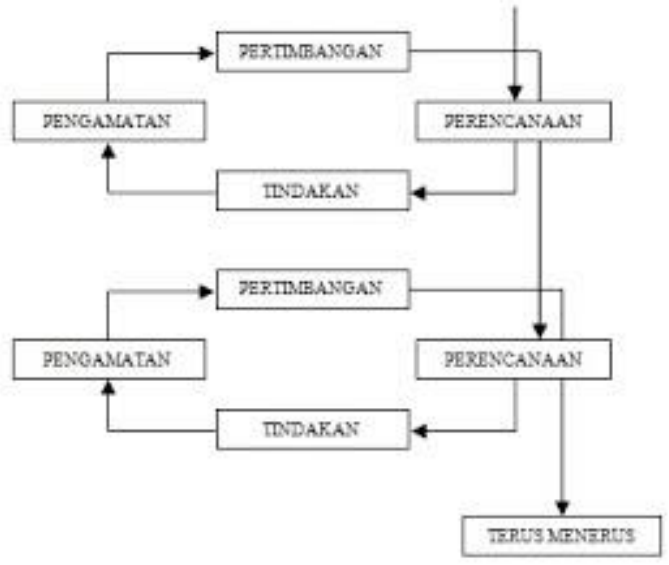

Gambar 3.1. PTK Model Lewin

\section{Model Kemmis dan Mc Taggart (1988)}

Model Kemmis dan Taggart merupakan pengembangan dari konsep dasar yang diperkenalkan Kurt Lewin, hanya saja komponen acting dan observing dijadikan satu kesatuan karena keduanya merupakan tindakan yang tidak terpisahkan, terjadi dalam waktu yang sama.

Dalam perencanaannya, Kemmis menggunakan sistem spiral refleksi diri yang dimulai dengan rencana (planning), tindakan (acting), pengamatan (observing), refleksi (reflecting), dan perencanaan kembali yang merupakan dasar untuk suatu ancang-ancang pemecahan permasalahan. Pola dasar model PTK 
menurut Kemmis \& Taggart ditunjukan pada gambar 3.2.
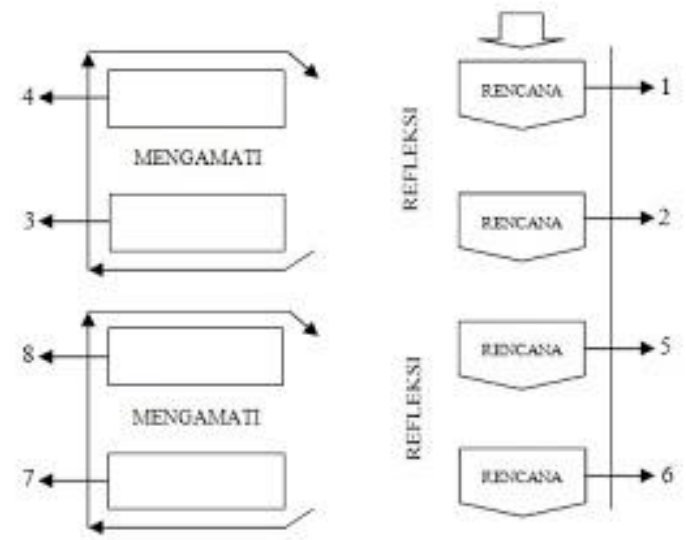

Gambar 3.2 PTK Model Spiral Kemmis \& Taggart

\section{Model Elliot (1991)}

Model ini diperkenalkan dan dikembangkan oleh Elliot. Elliot adalah seorang pendukung gerakan "guru sebagai peneliti”. Beliau selalu berusaha mencari cara-cara baru untuk mengembangkan jaringan penelitian. Tindakan dan berhubungan dengan pusat-pusat jaringan penelitian yang lain. Elliot dan delman bekerja bersamasama dengan guru di kelas, bukan hanya sebagai pengamat, tetapi mereka sebagai kolaborator atau teman sejawat guru. Melalui partisipasi semacam ini, mereka membantu guru untuk mengadopsi suatu pendekatan penelitian untuk pekerjaannya. Elliot setuju dengan ide dasar langkah-langkah tindakan refleksi yang terus bergulir dan kemudian menjadi suatu siklus seperti yang dikembangkan Kemmis. Namun, skema langkah-langkahnya lebih rinci dan berpeluang untuk lebih mudah diubah sehingga sebenarnya dia telah membuat suatu diagram yang lebih baik.

Ada hal-hal yang perlu diperhatikan dalam memahami langkahlangkah yang ada di dalam model PTK yang dikembangkan oleh Ebbut, Elliot dan Kemmis. Bila guru akan menerapkan atau mengadopsi untuk penelitian tindakan kelas dalam praktik di kelasnya, guru harus memahami betul apa yang dimaksud oleh masing-masing penulis. Di samping itu, guru atau peneliti harus mengetahui penggunaan data dan keterbatasan skema-skema tersebut bila dipraktikan dalam penelitian tindakan. Beberapa keterbatasan langkah-langkah di dalam model PTK ini antara lain:

(1) Adanya gerakan yang mulai menjauh dari gerakan ajaran Lewin semula

(2) Skema-skema kelihatannya rapuh dan membingungkan 
(3) Skema-skema tersebut tidak dapat menyesuaikan dengan hal-hal baru yang menjadi fokus utamanya, dan

(4) Skema tersebut tidak begitu saja cocok untuk diikuti.

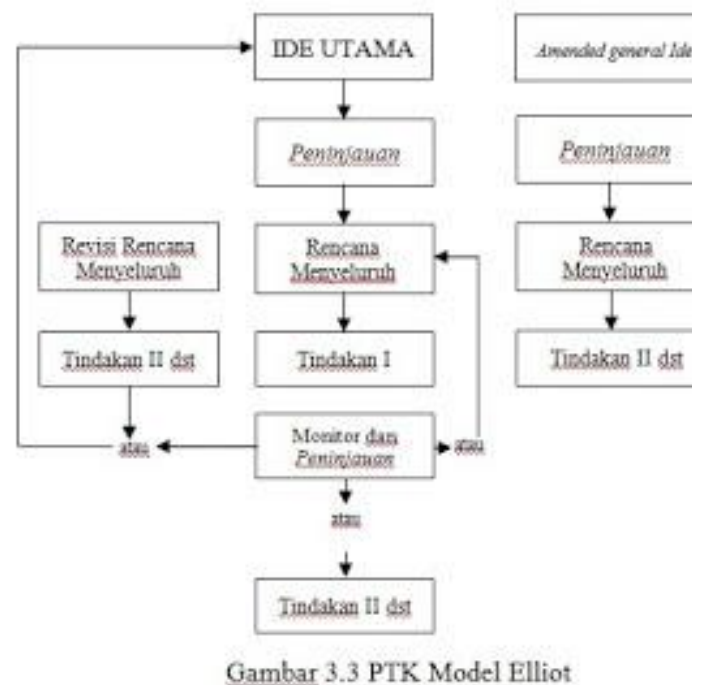

\section{Model Mc Kernan (1991)}

Sebuah model lain yang juga dikembangkan atas dasar ide Lewin atau yang diinterpretasikan oleh Kemmis adalah model penelitian tindakan $\mathrm{Mc}$ Kernan. Model ini juga dinamakan proses waktu (a time process model). Menurut Mc Kernan sangatlah penting untuk mengingat bahwa kita tidak perlu selalu terikat oleh waktu, terutama untuk pemecahan permasalahan hendaknya pemecahan masalah atau tindakan

Available at http://journal.unj.ac.id/unj/index.php/jpm dilakukan secara rasional dan demokratis.

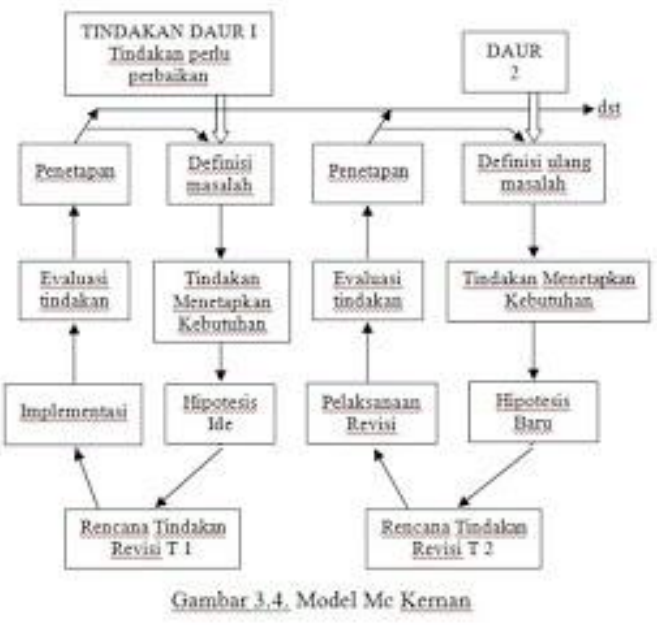

Model Ebbut (1985)

Sesuai dengan namanya, model PTK ini dikembangkan oleh Dave Ebbut. Model ini diilhami oleh pemikiran Kemmis dan Elliot. Dalam pengembangannya, Ebbut kurang begitu sependapat dengan interpretasi Elliot tentang karya Kemmis. Perasaan kurang setuju Ebbut (1983) disebabkan karena Kemmis menyamakan penelitiannya dengan hanya temuan fakta. Sedangkan kenyataannya, Kemmis dengan jelas menunjukan bahwa penelitian terdiri atas diskusi, negosiasi, menyelidiki dan menelaah kendala-kendala yang ada. Jadi sudah jelas ada elemen-elemen analisisnya dalam model Kemmis. 
Selanjutnya, Ebbut berpendapat bahwa langkah-langkah yang dikembangkan oleh Kemmis ("Spiral Kemmis") bukanlah yang paling baik untuk mendeskripsikan adanya proses tindakan dan refleksi. Memang pada kenyataannya, Ebbut sangat memperhatikan alur logika penelitian tindakan dan beliau juga berusaha memperlihatkan adanya perbedaan antara teori sistem dan membuat sistemsistem tersebut ke dalam bentuk kegiatan operasional. Secara rinci alur PTK Ebbut ditunjukan pada gambar 3.5.

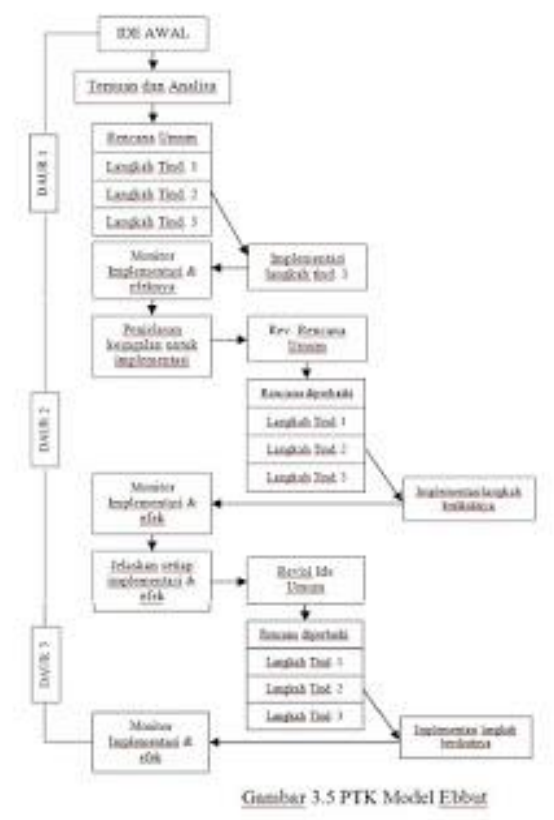

Tujuan menyajikan keempat model ini adalah agar pembaca memiliki

Available at http://journal.unj.ac.id/unj/index.php/jpm wawasan yang lebih luas tentang penelitian tindakan. Selain itu, jika seseorang mengenal lebih dari satu model penelitian tindakan diharapkan bahwa dia memperoleh suatu pemahaman yang lebih tentang suatu proses. Walaupun kenyataannya ada empat model, pada dasarnya keempat model ini lebih banyak memiliki "persamaan" daripada "perbedaan".

Perlu diketahui bahwa sebenarnya model-model ini lebih memberikan gambaran garis besar proses dari pada suatu teknologi. Urutan langkah-langkah memang diperhatikan, tetapi hanya sedikit sekali yang menyinggung soal 'apa' dan 'bagaimana' antara langkahlangkah ini. Tidak mengherankan kalau model-model ini dapat membingungkan para praktisi. Bahkan Ebbut sendiri mengakui bahwa gambar Elliot cenderung sulit dimengerti.

Namun demikian, berdasarkan rujukan tersebut, secara umum pola dasar dari model-model tersebut meliputi empat tahapan: Pertama, penyusunan rencana (planning); Kedua, melakukan tindakan (acting); Ketiga, pengamatan (observing); dan Keempat, refleksi (reflecting). Dan yang perlu 
dipahami bahwa, tahapan pelaksanaan dan pengamatan sesungguhnya dilakukan secara bersamaan. Secara lengkap pola dasar model PTK ditunjukan dalam gambar 3.6. berikut:

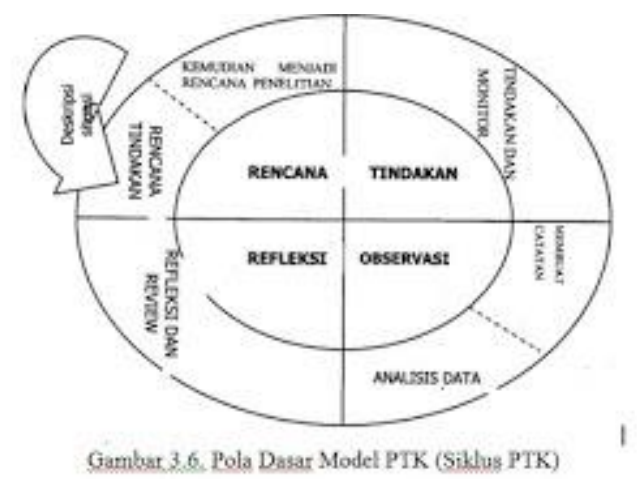

Tahap 1: Perencanaan tindakan (planning)

Berdasarkan identifikasi masalah yang dilakukan pada tahap pra PTK, rencana tindakan disusun untuk menguji secara empiris hipotesis tindakan yang ditentukan. Rencana tindakan ini mencakup semua langkah tindakan secara rinci. Segala keperluan pelaksanaan PTK, mulai dari materi/bahan ajar, rencana pengajaran yang mencakup metode/teknik mengajar, serta teknik atau instrumen observasi/evaluasi, dipersiapkan dengan matang pada tahap perencanaan ini. Dalam tahap ini perlu juga diperhitungkan segala kendala yang

Available at http://journal.unj.ac.id/unj/index.php/jpm mungkin timbul pada saat tahap implementasi berlangsung. Dengan melakukan antisipasi lebih dari diharapkan pelaksanaan PTK dapat berlangsung dengan baik sesuai dengan hipotesis yang telah ditentukan.

Tahap 2: Pelaksanaan tindakan (Acting)

Tahap ini merupakan implementasi (pelaksanaan) dari semua rencana yang telah dibuat. Tahap ini, yang berlangsung di dalam kelas, adalah realisasi dari segala teori pendidikan dan teknik mengajar yang telah disiapkan sebelumnya. Langkah-langkah yang dilakukan guru tentu saja mengacu pada kurikulum yang berlaku, dan hasilnya diharapkan berupa peningkatan efektivitas keterlibatan kolaborator sekedar untuk membantu si peneliti untuk dapat lebih mempertajam refleksi dan evaluasi yang dia lakukan terhadap apa yang terjadi di kelasnya sendiri. Dalam proses refleksi ini segala pengalaman, pengetahuan dan teori pembelajaran yang dikuasai dan relevan.

\section{Tahap 3: Pengamatan terhadap} tindakan (Observing)

Kegiatan observasi dilakukan bersamaan dengan pelaksanaan 
tindakan. Data yang dikumpulkan pada tahap ini berisi tentang pelaksanaan tindakan dan rencana yang sudah dibuat, serta dampaknya terhadap proses dan hasil intruksional yang dikumpulkan dengan alat bantu instrument pengamatan yang dikembangkan oleh peneliti. Pada tahap ini perlu mempertimbangkan penggunaan beberapa jenis instrument ukur penelitian guna kepentingan triangulasi data. Dalam melaksanakan observasi dan evaluasi, guru tidak harus bekerja sendiri. Dalam tahap observasi ini guru bisa dibantu oleh pengamat dari luar (sejawat atau pakar). Dengan kehadiran orang lain dalam penelitian ini, PTK yang dilaksanakan menjadi bersifat kolaboratif. Hanya saja pengamat luar tidak boleh terlibat terlalu dalam dan mengintervensi terhadap pengambilan keputusan tindakan yang dilakukan oleh peneliti. Terdapat empat metode observasi, yaitu: observasi terbuka; observasi terfokus; observasi terstruktur dan observasi sistematis. Beberapa prinsip yang harus dipenuhi dalam observasi, diantaranya (a) ada perencanaan antara dosen/guru dengan pengamat; (b) fokus observasi harus

\section{Available at} http://journal.unj.ac.id/unj/index.php/jpm ditetapkan bersama; (c) dosen/guru dan pengamat membangun kriteria bersama; (d) pengamat memiliki ketrampilan mengamati; dan (e) balikan hasil pengamatan diberikan dengan segera. Adapun ketrampilan yang harus dimiliki pengamat diantaranya: (a) menghindari kecenderungan untuk membuat penafsiran; (b) adanya keterlibatan ketrampilan antar pribadi; (c) merencanakan skedul aktivitas kelas; (d) umpan balik tidak lebih dari 24 jam; (d) catatan harus teliti dan sistematis.

Tahap 4: Refleksi terhadap tindakan (reflecting)

Tahapan ini merupakan tahapan untuk memproses data yang didapat saat dilakukan pengamatan. Data yang didapat kemudian ditafsirkan dan dicari eksplanasinya, dianalisis dan disintesis. Dalam proses pengkajian data ini dimungkinkan melibatkan orang luar sebagai kolaborator, seperti halnya pada saat observasi. Keterlibatan kalaborator sekedar untuk membantu peneliti untuk dapat lebih tajam melakukan refleksi dan evaluasi. Dalam proses refleksi ini segala pengalaman, pengetahuan dan teori instruksional yang dikuasai dan relevan dengan tindakan kelas yang 
dilaksanakan sebelumnya, menjadi bahan pertimbangan dan perbandingan sehingga dapat ditarik suatu kesimpulan yang mantap dan sahih. Proses refleksi ini memegang peran yang sangat penting dalam menentukan suatu keberhasilan PTK.

Dengan suatu refleksi yang tajam dan terpercaya akan didapat suatu masukan yang sangat berharga dan akurat bagi penentuan langkah tindakan selanjutnya. Refleksi yang tidak tajam akan memberikan umpan balik yang menyesatkan dan bias, yang pada akhirnya menyebabkan kegagalan suatu PTK. Tentu saja kadar ketajaman proses refleksi ini ditentukan oleh ketajaman dan keragaman instrument observasi yang dipakai sebagai upaya triangulasi data. Observasi yang hanya menggunakan satu instrumen saja. Akan menghasilkan data yang miskin. Adapun untuk memudahkan dalam refleksi bisa juga dimunculkan kelebihan dan kekurangan setiap tindakan dan ini dijadikan dasar perencanaan siklus selanjutnya. Pelaksanaan refleksi diusahakan tidak boleh lebih dari 24 jam artinya begitu selesai observasi langsung diadakan refleksi bersama kolaborator.

Available at http://journal.unj.ac.id/unj/index.php/jpm
Demikian, secara keseluruhan keempat tahapan dalam PTK ini membentuk suatu siklus. Siklus ini kemudian diikuti oleh siklus-siklus lain secara bersinambungan seperti sebuah spiral.

Kapan siklus-siklus tersebut berakhir? Pertanyaan ini hanya dapat dijawab oleh si peneliti sendiri. Kalau dia sudah merasa puas terhadap hasil yang dicapai dalam suatu kegiatan PTK yang dia lakukan, maka dia akan mengakhiri siklus-siklus tersebut. Selanjutnya, dia akan melakukan satu identifikasi masalah lain dan kemudian diikuti oleh tahapan-tahapan PTK baru guna mencari solusi dari masalah tersebut.

\section{Bentuk-Bentuk PTK}

Selain jenis-jenis dan modelmodel PTK, dikenal juga bentuk-bentuk PTK. Setidaknya dikenal 4 (empat) bentuk penelitian tindakan, yaitu : (1) penelitian tindakan guru sebagai peneliti; (2) penelitian tindakan kolaboratif; (3) penelitian tindakan simultan terintegrasi; dan (4) penelitian tindakan administrasi sosial eksperimen

Keempat bentuk PTK di atas, memiliki persamaan dan perbedaan. 
Ciri-ciri dari setiap penelitian tindakan tergantung pada : (1) tujuan utama atau pada tekanan penelitian tersebut; (2) tingkat kolaborasi antara pelaku peneliti dan peneliti luar; (3) proses yang digunakan dalam melaksanakan penelitian; dan (4) hubungan antara proyek dengan sekolah.

Perbedaan dalam penelitian tindakan yang terjadi di beberapa negara mencerminkan prioritas dan pandangan pendidikan serta penelitian. Misalnya, penelitian tindakan di Inggris dan Australia, ada persamaan dalam hal bentuk kolaborasinya. Namun demikian, PTK di Inggris kurang berorientasi pada strategis dan lebih menekankan penelitian penafsiran. Sedangkan di Australia, PTK lebih berorientasi pada gurunya.

Berikut dipaparkan keempat bentuk PTK yang telah dikenal selama ini dan banyak dikembangkan di beberapa negara termasuk di Indonesia.

\section{PTK Guru sebagai Peneliti}

PTK yang memandang guru sebagai peneliti memiliki ciri-ciri penting, antara lain : sangat berperannya guru itu sendiri dalam proses penelitian. Dalam bentuk ini, tujuan utama PTK ialah meningkatkan praktik-praktik pembelajaran di kelas. Dalam kegiatan ini, guru terlibat secara langsung dan penuh dalam proses perencanaan, tindakan, observasi, dan refleksi.

Dalam penelitian bentuk ini, guru mendapat problem sendiri untuk dipecahkan melalui PTK. Jika di dalam penelitian ini, peneliti melibatkan pihak lain, maka perananya tidak dominan. Sebaliknya, keterlibatan pihak lain dari luar hanya bersifat konsultatif dalam mencari dan mempertajam persoalanpersoalan pembelajaran yang dihadapi oleh guru yang sekiranya layak untuk dipecahkan melalui penelitian-penelitian tindakan kelas. Jadi, guru di dalam melaksanakan penelitian tindakan berperan sebagai peneliti. Sedangkan pihak luar sebenarnya peranannya sangat kecil dalam proses penelitian itu.

\section{PTK Kolaboratif}

Penelitian tindakan ini melibatkan beberapa pihak, yaitu guru, kepala sekolah, dosen LPTK dan orang lain yang terlibat menjadi satu tim secara serentak melakukan penelitian dengan tiga tujuan, yaitu : (1) meningkatkan praktik pembelajaran, (2) menyumbang 
pada perkembangan teori, dan (3) meningkatkan karier guru.

Bentuk penelitian seperti ini, pihak luar semata hanya bertindak sebagai inovator. Sedangkan guru juga dapat melakukannya melalui bekerja sama dengan dosen LPTK/ PGSD. Dengan suasana bekerja seperti itu, guru dan dosen LPTK/PGSD dapat saling mengenal, saling belajar, dan saling mengisi proses peningkatan profesionalisme masing-masing.

\section{PTK Simultan Terintegrasi}

Penelitian tindakan terintegrasi adalah bentuk penelitian tindakan yang bertujuan untuk dua hal sekaligus, yaitu untuk memecahkan persoalan praktis dalam pembelajaran dan menghasilkan pengetahuan yang ilmiah dalam bidang pembelajaran di kelas. Dalam pelaksanaan tindakan kelas yang demikian, guru dilibatkan dalam proses penelitian kelasnya, terutama pada aspek aksi dan refleksi terhadap praktikpraktik pembelajaran di kelas.

Dalam hal ini, persoalan-persoalan pembelajaran yang diteliti muncul dan diidentifikasi oleh peneliti dari luar bukan guru. Jadi, dalam bentuk ini, guru bukan pencetus gagasan terhadap permasalahan apa yang harus diteliti dalam kelasnya sendiri. Dengan demikian, guru bukan innovator dalam penelitian ini dan sebaliknya yang mengambil posisi innovator adalah peneliti lain di luar guru.

\section{PTK Administrasi Sosial}

\section{Eksperimen}

Ada suatu bentuk penelitian tindakan yang pelaksanaannya lebih meningkatkan dampak kebijakan dan praktik. Dalam penelitian tindakan ini, guru tidak dilibatkan dalam menyusun perencanaan, melakukan tindakan dan refleksi terhadap praktik pembelajarannya sendiri di dalam kelas. Jadi, sebenarnya guru tidak banyak memberikan masukan dalam proses pelaksanaan penelitian tindakan jenis ini. Tanggung jawab penuh penelitian tindakan ini terletak pada pihak luar, meskipun objek penelitian itu terletak di dalam kelas.

Dalam melakukan penelitian tindakan administrasi sosial eksperimental, peneliti bekerja atas dasar hipotesis tertentu. Penelitian luar yang membuat rencana tindakan dan kegiatan pelaksanaan penelitiannya mengacu pada hipotesis tertentu. 
Selanjutnya, peneliti melakukan berbagai tes yang ada dalam eksperimennya.

Jadi, berdasarkan uraian di atas dapat disarikan bahwa dalam rangka upaya menambah pemahaman dan wawasan tentang penelitian tindakan kelas perlu diketahui beberapa tipologi, model dan bentuk penelitian tindakan. Dengan demikian guru dapat memilih mana sekiranya yang cocok bagi mereka untuk mengembangkan dalam proses pembelajaran sehingga kualitas pembelajaran yang bermuara pada hasil belajar siswa dapat menunjukan peningkatan yang signifikan.

\section{MATERI DAN METODE}

\section{Kerangka Pemecahan Masalah}

Rendahnya kualitas penulisan artikel ilmiah PTK oleh para guru-guru Ekonomi yang tergabung dalam MGMP Kabupaten Sidoarjo, membuat pentingnya dilaksanakan pendampingan penulisan proposal penelitian Tindakan Kelas (PTK).

\section{Realisas Pemecahan Masalah}

Kegiatan pengabdian kepada masyarakat dilakukan dengan cara mengadakan Pelatihan Penulisan

Available at http://journal.unj.ac.id/unj/index.php/jpm
Proposal Penelitian Tindakan Kelas (PTK). Adapun realisas kegiatan PKM sebagai berikut :

1. Persiapan Sosialisasi Program

Program pengabdian kepada masyarakat disampaikan kepada sekolah, guru dan direspon positif. Selanjutnya kegiatan dikoordinasikan oleh Tim Pelaksana yaitu dengan cara menyampaikan informasi pelaksanaan Penulisan Penelitian Tindakan Kelas (PTK).

2. Pendataan Guru

Melakukan pendataan guru-guru yang mengikuti pelatihan Penulisan Penelitian Tindakan Kelas (PTK). Banyaknya guru peserta PKM \pm 23 orang yaitu guru-guru SMA yang tergabung dalam MGMP Ekonomi Kabupaten Sidoarjo.

3. Menyusun TIM pelaksana Pengabdian Masyarakat Tingkat Jurusan.

Membentuk tim pelatihan proposal penelitian tindakan kelas, yang terdiri dari dosen-dosen Jurusan Pendidikan Ekonomi yang mempunyai pengalaman dan keahlian di bidan PTK. 
4. Pengajuan Proposal Pengabdian Masyarakat

Berdasarkan observasi kebutuhan sekolah tersebut, diajukan kegiatan pelatihan tindakan kelas untuk guruguru SMA yang tergabung dalam MGMP Ekonomi Kabupaten Sidoarjo dan kepada mitra SMA Sidoarjo.

5. Proposal diterima kemudian pelatihan dilaksanakan. Pelatihan dilakukan dua periode: 1) penyampaian materi serta pemberian tugas pembuatan proposal PTK, dan 2) telaah proposal PTK oleh para peserta PKM. Dari hasil pelatihan ini, diharapkan menghasilkan luaran berupa proposal penelitian tindakan kelas.

\section{Khalayak Sasaran}

Peserta pengabdian kepada masyarakat adalah guru-guru SMA yang tergabung dalam MGMP Kabupaten Sidoarjo. Peserta PKM dibatasi hanya \pm 25 orang yang tergabung dalam MGMP Ekonomi Kabupaten Sidoarjo. Sesuai dengan harapan Pemerintah (Dikti, 2006) guru harus selalu mengembangan kompetensi secara berkelanjutan, sesuai dengan bidangnya masing-masing.

Seperti harapan Pemerintah (Dikdasmen, 2006), Lembaga pengabdian masyarakat dan fakultas ekonomi telah membina hubungan melalui berbagai kesempatan. Workshop serta pelatihan yang ada dalam usaha membina dan meningkatkan pola pemikiran serta pengetahuan guru-guru, khususnya guruguru Ekonomi SMA yang tergabung dalam MGMP Ekonomi Kabupaten Sidoarjo.

\section{Metode}

Berikut metode yang dilakukan:

1. Metode Pelaksanaan : ceramah bervariasi, praktek, diskusi dan tanya jawab.

2. Materi Pelatihan:

a. Konsep dasar penelitian tindakan kelas (PTK)

b. Hakekat Penelitian tindakan kelas (PTK)

c. Metodologi Penelitian Tindakan Kelas

d. Sistematika Proposak Penelitian Tindakan Kelas (PTK)

3. Penyusunan proposal Penelitian Tindakan Kelas (PTK) oleh peserta 
Telaah proposal Penelitian Tindakan Kelas (PTK)

\section{HASIL DAN PEMBAHASAN}

Pelaksanaan pengabdian kepada masyarakat (PKM) dengan tema "Pelatihan Pelatihan Penulisan Penelitian Tindakan Kelas Bagi Guru Ekonomi SMA di Kabupaten Sidoarjo" dapat menghasilkan draft proposal penelitian tindakan kelas (PTK) dari para guru yang selanjutnya dapat digunakan untuk melakukan penelitian tindakan kelas (PTK).

Secara garis besar penyajian hasil pengabdian kepada masyarakat (PKM) Pelatihan Penulisan Penelitian Tindakan Kelas Bagi Guru Ekonomi SMA Kabupaten Sidoarjo sebagai berikut:

Kegiatan pengabdian ini merupakan kegiatan yang harus mampu mensinergikan beberapa unsur dalam sistem pendidikan sebagai salah satu upaya mendukung peningkatan mutu pendidikan maka kegiatan pengabdian ini dilaksanakan sebagai berikut:

Tahap pertama dalam kegiatan ini adalah pembukaan kegiatan yang isi kegiatannya adalah pembukaan dan sambutan oleh Ketua MGMP mata

Available at http://journal.unj.ac.id/unj/index.php/jpm pelajaran Ekonomi Kabupaten Sidoarjo dilanjutkan sambutan Yoyok Soesatyo mewakili tim Pengabdian kepada Masyarakat Unesa, dilanjutkan penjelasan umum tentang program pengabdian. Ketua MGMP dalam sambutannya sangat mengaharapkan peserta dapat meningkatkan kualitas profesi secara berkelanjutan sebagai tanggung profesionalnya untuk selalu meningkatkan kualitas pembelajaran. Peserta dihimbau untuk mengikuti acara pelatiahan ini dngan sungguh-sungguh untuk selanjutkan bisa diterapkan penelitiannya di kelasnya masingmasing. Sambutan dari tim PKM Jurusan Pendidikan Ekonomi fakultas Ekonomi Universiats Negeri Surabaya, Prof. Yoyok Soesatyo mengharapkan kerjasama ini tidak berhenti sampai disini. Di waktu yang akan datan kerja sama ini bisa ditingkatkan bahkan kalau mungkin dikembangkan ke bidang yang lain.

Tahap kedua pelaksanaan pelatihan penulisan Penelitian Tindakan Kelas (PTK) materi disampaikan oleh Yoyok Soesatyo dengan moderator Nurida Canda Sakti. Topik kajiannya tentang Konsep Dasar Penelitian 
Pendidikan dan Konsep dan Karakteristik PTK. Tahap ini dilaksanakan secara klasikal (ceramah). Secara ilmiah, penulisan penelitian tindakan kelas ini perlu dikuasai oleh guru-guru SMA, khususnya guru mata pelajaran Ekonomi. Penguassa terhadap PTK ini akan melatih pada guru untuk mengembangkan kualitas diri secara berkelanjutan. Kalau sudah terbiasa melakukan penelitian tindakan kelas dan penelitian lainnya, pada guru akan merasa tidak terbebani dalam melaksanakan peneltian tindakan kelas, karena sudah terbiasa. Pembiasaan penulisan penelitian tindakan kelas ini memang sulit dilakukan oleh siapaun, tetapi dengan keasadaran tinggi untuk meningkatkan kualitas diri, hal itu akan mudah dilakukan di dalam pekerjaan sehari-hari. Tantangannya ada pada motivasi masing-masing individu para guru, untuk berkembang meningkatkan kualitas diri berkelanjutan.

Tahap ketiga presentasi disampaikan oleh Waspodo Tjipto Subroto dan di moderatori oleh Muhammad Edwar ini, membahas tentang teknik penyusunan proposal PTK dilanjutkan dengan laporan PTK yang kemudian di tulis artikelnya untuk publikasi ilmiah. Tahap ini peserta diminta menyusun draft proposal penelitian tindakan kelas (PTK). Dengan sistematika yang telah disampaikan. Peserta secara mandiri menyusun draft proposal penelitian tindakan kelas (PTK) dengan pendampingan tim pengabdian. Para pendamping dalam kegiatan Pelatihan Penulisan Penelitian Tindakan Kelas ini antara lain Nurida Canda Sakti, dan Muhammad Edwar serta Novi Trisnawati

Tahap keempat Pembimbingan proposal PTK melalui kegiatan workshop. Tahap ini memberikan fasilitas bagi peserta pelatihan yang membutuhkan konsultasi atau bimbingan. Workshop dilaksanakan melalui 2 sesi, yaitu sesi pertama: menyusun draft proposal PTK, didampingi Nurida Candasakti dan Muhamamad Edwar serta Novi Trisnawati. Dilanjutkan dengan workshop sesi 2 yang bertujuan menghasilkan draft akhir proposal penelitian tindakan kelas.

Selain itu untuk kelanjutan dari pelaksanaan pelatihan penulisan proposal PTK ini. 


\section{Kesimpulan}

Berdasarkan pembahasan di atas, dapat disimpulkan hal-hal sebagai beriku:

1. Pelaksanaan PKM Jurusan S1 Pendidikan Ekonomi Unesa kepada guru-guru SMA di kabupaten Sidoarjo terlaksana sesuai dengan tujuan dan diikuti oleh 22 guru-guru mata pelajaran Ekonomi SMA di Kabupaten Sidoarjo.

2. Dalam kegiatan workshop PKM, dihasilkan 20 draft proposal PTK yang disusun oleh para peserta.

3. Perlu pendampingan lebih lanjut untuk melaksanakan PTK di sekolah masing-masing peserta sampai penyusunan Laporan PTK.

\section{Saran}

Dari simpulan hasil pelaksanaan PKM di atas, disarankan hal-hal sebagai berikut:

1. Pelaksanaan PPM Jurusan S1

Pendidikan Ekonomi Fakultas

Ekonomi Unesa kepada guru-guru

SMA dapat dilaksanan pada kabupaten-kabupaten lain di jawa Timur.

2. Pendampingan dalam workshop PKM, perlu dilanjutkan sampai pelaksanaan PTK di kelas-kelas peserta PKM

3. Pelaksanaan PKM bisa dikembangkan pada Keterampilan Penulisan Karya Ilmiah bagi guruguru SMA mata pelajaran Ekonomi untuk publikasi ilmiah di jurnaljurnal ilmiah.

\section{DAFTAR PUSTAKA}

http://gurukumiisjtg.blogspot.co.id/2014 /04/model-model-penelitiantindakan-kelas.html

http://edriati.blogspot.co.id/2016/03/mo del-model-penelitian-tindakankelas_23.html

Akbar, Sa'dum. 2010. PTK: Filosofi, Metodologi dan Implementasinya (Edisi Revisi). Yogyakarta: Cipta Media Aksara Hidayat, Komariddin. 2009. Active Learning: $101 \quad$ Srategi Pembelajaran Aktif. Yogyakarta: Insan Masani

Muslich, Masnur. 2009. Melaksanakan PTK (Penelitian Tindakan Kelas) itu Mudah. Jakarta: Bumi Aksara Suharsimi, Arikunto; Suhardjono; Supardi. 2007. Penelitian Tindakan Kelas. Jakarta: Bina Aksara 